\title{
Promjene u okolišu i ljudske migracije
}

DOI: $10.11567 /$ met.30.3.3

UDK: $314: 502 / 504$

Pregledni rad

Primljeno: 15.12.2014.

Prihvaćeno: 3.2.2015.

\section{Milan Mesić}

Odsjek za sociologiju, Filozofski fakultet Sveučilišta u Zagrebu, Zagreb

mmesic@ffzg.hr

\section{Drago Župarić-Iljić}

Institut za migracije i narodnosti, Zagreb

drago.zuparic@imin.hr

\section{SAŽETAK}

Tridesetu obljetnicu časopisa Migracijske i etničke teme (MET) autori su shvatili kao prigodu da najave novu ključnu problematiku suvremenoga svijeta i njegove budućnosti, koja po njihovu sudu postaje upravo i središnja tema multidisciplinarnog i interdisciplinarnog područja migracijskih studija. Riječ je o raseljavanju ljudi u lokalnim i državnim okvirima te migracijama preko državnih granica, na regionalnoj i globalnoj razini, izazvanima, neposredno ili posredno, promjenama okoliša. Recentna genetska istraživanja nastanka i razvoja ljudske vrste dodatno potvrđuju da su ljudske ekološke migracije prvi i najstariji tip migracija uopće. K tome, kako sugeriraju arheološki i drugi nalazi, upravo su one ponekad igrale i ključnu ulogu u nastanku, propadanju i mijenjanju starih civilizacija. Čini se da su rani istraživači migracijskih studija imali dosta toga u vidu kad su promjene prirodnoga okoliša smatrali važnom odrednicom ljudskoga kretanja $u$ prostoru. Taj je interes $u$ društvenim znanostima zamro sve do druge polovine osamdesetih godina 20. stoljeća, kada se ponovno javlja. Autori prihvaćaju podjelu na uzročne kategorije »okolišnih migracija «: a) »prirodne« katastrofe; b) »urbanoindustrijske« katastrofe i c) iskorištavanje i degradacija resursa. Zatim se bave određenjem osnovnih pojmova, ponajprije prijeporom u vezi s određenjem »okolišnih izbjeglica« naspram »okolišnih migranata«. Naposljetku sistematiziraju dva glavna suprotstavljena pristupa migracijama i migrantima uvjetovanim promjenama okoliša. Prvi predstavljaju »alarmatičari«, a drugi »skeptici«. Skeptici, srećom, mogu (za sada) dokazivati da se zastrašujući crni scenariji o sve snažnijim i nezaustavljivim valovima okolišnih migranata (izbjeglica) ipak nisu ostvarili te da okolišni pokretači ljudskih migracija ne djeluju izolirano, nego u složenim sklopovima ekonomskoga, socijalnog i političkoga (ne)razvoja pojedinih političkih zajednica i cijelih regija. Ipak, oni, kao ni bilo tko drugi, ne mogu, nažalost, uvjerljivo osporiti da samo jedna kataklizmička prirodna katastrofa (kao što je udar meteora u Zemlju) može izazvati uništenje (dijela) čovječanstva i pretvaranje velikih dijelova našeg planeta u beživotna područja. Ako je ova naša (protuprirodna) civilizacija osuđena na propast, okolišni čimbenici, po svemu sudeći, bit će među njezinim grobarima.

KLJUČNE RIJEČI: okolišne migracije, okolišni migranti, okolišne izbjeglice, promjene okoliša, klimatske promjene 


\section{UVOD UZ OSOBNU NOTU}

Trideseta obljetnica Migracijskih i etničkih tema (MET), znanstvenoga časopisa s područja migracijskih studija, u kojem se u svjetskoj znanstvenoj zajednici mogu naći relativno rijetki primjeri starijih specijaliziranih časopisa, prilika je, po našem sudu, za nekoliko vrsta radova. Prvo, za kritičku sistematizaciju i evaluaciju, ako ne "razvoja«, onda barem usmjerenja i doprinosa migracijskim i etničkim (multidisciplinarnim i interdisciplinarnim) studijama, koje su se, uostalom, jako približile - konceptualno i metodološki - već u drugoj polovini sedamdesetih godina 20. stoljeća, osobito u odnosu na stanje prije pojave časopisa. Ovdje ćemo samo napomenuti da se u vrijeme pokretanja MET-a (znanstveni) diskurs o »vanjskim « migracijama uglavnom svodio na rudimentarna (sociološka) anketiranja »jugoslavenskih radnika na privremenom radu u inozemstvu«, provođenih u vrijeme njihova dolaska za božićne i novogodišnje praznike u zemlju, čiji su nalazi u pravilu potvrđivali orijentaciju na povratak izrazite većine (i više od osamdeset posto) migranata, što se, naravno, nije ostvarilo jer su već od druge polovine sedamdesetih počeli procesi spajanja obitelji u zemljama primitka migranata i pretvaranja migrantskih zajednica u trajne migrante. Kad je riječ o »drugoj generaciji«, socijaliziranoj i akulturiranoj u novim sredinama, nikakve dopunske škole ni nastava materinskog jezika nisu mogle značajnije potaknuti njihov »povratak «. Ekonomisti su se pak bavili migrantskim doznakama i njihovom važnošću za ekonomski »razvoj« zemlje. Druga vrsta (obljetničarskoga) rada bila bi utvrđivanje state of the art na području migracijskih i etničkih studija kod nas, pa i u svijetu.

I treća, koja vjerojatno (pret)postavlja najlakši zadatak, koji smo (i) mi izabrali: istaknuti jednu, do sada zanemarenu problematiku, koja će, po svemu sudeći, u idućem razdoblju postati sve izazovnija za migracijske studije. Naime kad su 1985. tadašnji ravnatelj Centra za istraživanje migracija i poslije Instituta za migracije i narodnosti M. Mesić i E. Heršak pokrenuli Migracijske teme (poslije Migracijske i etničke teme), migracije kao posljedica (novijih) promjena u okolišu nisu bile tema migracijskih studija, posebno ne kod nas. No već 1992. Mesić je objavio prvi članak na temu ekoloških migracija, u Socijalnoj ekologiji, u prvoj godini njezina izlaženja (Mesić, 1992). Napokon, deset godina poslije, u svoj sveučilišni udžbenik Međunarodne migracije - tokovi $i$ teorije taj je autor uvrstio dva kratka poglavlja, jedno o pretpovijesnim migracijama i drugo o (vjerojatnoj) povezanosti ekomigracija i civilizacija. Bez ulaženja u temeljnu raspravu došao je do zaključka da je sama ljudska vrsta, na neki način, nastajala i širila se u migracijama, koje su 
tijekom cijele prethistorije, kao i historije čovječanstva, nastanka i nestanka civilizacija i kultura, bile neposredno ili posredno uvjetovane promjenama u okolišu (Mesić, 2002: 18-20). Napokon, D. Župarić-Iljić priprema prvu doktorsku disertaciju o okolišnim (prisilnim) migracijama. Trideseta obljetnica izlaženja Migracijskih $i$ etničkih tema dobra je prilika da ovim člankom istaknemo sve veću važnost (pa i dramatičnost) migracija uvjetovanih promjenama okoliša, osobito za narode u nerazvijenim dijelovima svijeta, ali i čovječanstvo u cjelini, a time i za migracijske studije, kao istraživačko područje na kojemu se susreću ne samo društvene nego i prirodne discipline, ali i »visoka «strateška nacionalna i međunarodna politika. I po tome one se nadáju kao postmoderna problematika koja ruši tradicionalna disciplinska ograđivanja. Naravno, postoje i druge relevantne teme, koje do sada nisu privukle dovoljnu pozornost ni u časopisu ni na području migracijskih studija općenito.

U nastavku ističemo usmjerenost ranih istraživača na području migracija na promjene $u$ okolišu kao jednom od važnih pokretača preseljavanja ljudi, ljudskih grupa, pa i cijelih kultura i civilizacija. Zatim se bavimo određenjem osnovnih pojmova vezanih uz okolišne migracije pa u osnovnim crtama naznačujemo vrijeme i okvir jednoga novog migracijskoga obzora iz kojega promjene u okolišu postaju jedno od ključnih (premda kontroverznih) pitanja raseljavanja i migracija ljudi na nacionalnoj, regionalnoj i globalnoj razini. U tom smislu sistematiziramo različite pristupe okolišnim čimbenicima tih migracija te njihove glavne tipove s primjerima. Na kraju iznosimo kratke zaključke.

\section{MIGRACIJSKE STUDIJE:PONOVNO OTKRIVANJE OKOLIŠNIH MIGRACIJA}

Ljudske migracije zbog promjena u okolišu prvi su i najstariji tip migracija uopće. Današnji antropolozi uvelike su suglasni da je kolijevka ljudskih predaka u Istočnoj Africi. To se odnosi i na homo sapiensa, koji se pojavio prije nekih 160.000 godina, čija se populacija procjenjuje na desetak tisuća, i njihove gene nose sva ljudska bića danas, od Afrike do Australije. ${ }^{1}$ "Samo « tridesetak tisuća godina poslije ta bića započinju svoje migracije, koje se neće zaustaviti dok ne nasele gotovo sve naseljive prostore na Zemlji. Ljudi su oduvijek bili pokretljivi u prostoru tijekom svoje cijele prethistorije i rane historije, kao i u moderno doba (Heršak, 2005; Münz i Reiterer, 2007: 22-23, 126).

Manning (2008: 19) početak ljudske vrste pomiče na 200.000 godina. 
Za našu raspravu važno je istaknuti da postoje indikacije, koje suvremena klimatološka znanost istražuje, koje upućuju da je klima u Africi oko 100.000 godina oscilirala između suša i poplava prije nego što je postala relativno stabilna prije nekih 70.000 godina. Možda je nestabilnost okoliša natjerala rane ljudske grupe da postanu inventivnije i pokretljivije i započnu svoju prvu prekomorsku migraciju, s Roga Afrike u Malu Aziju (Douglas, 2012: 40-41).

Arheološki i drugi nalazi sugeriraju da su migracije, od kojih su neke ponajprije ekološki inducirane, igrale stanovitu ulogu u nastanku, propadanju i mijenjanju starih civilizacija (Mesić, 2002: 23). Civilizacije Sumera, Egipta i Kine ubrzale su svoj razvoj u razdoblju (i)migracija. Desifikacija afroazijske stepe tako je prisilila pretke drevnih Egipćana da migriraju u dolinu Nila, gdje su, prilagođujući se novoj sredini, stvorili civilizaciju (Toynbee, 1987: 49, 62-63, 70-73). Izgleda da su Egipat i Sumer nastanjeni razmjerno kasno u prethistoriji (vjerojatno zbog nepristupačnosti doline Nila i južne Mezopotamije), a i tada zahvaljujući postupnom smanjivanju oborina na dijelu sjeverne Afrike i Prednje Azije. To je bio ekološki potisni čimbenik seobe tih ljudi prema vlažnijim (nenaseljenim) područjima oko Nila, Eufrata i Tigrisa. Prije četiri tisuće godina produžena suša i time izazvana glad stanovništva u Kanaanu natjerale su biblijskoga Jakova i njegove sinove u Egipat, da bi potomke tih (eko)migranata Mojsije poveo »natrag « u prostore njihovih predaka. Moguće je da je propast Akadskoga Carstva u Mezopotamiji, prije oko 4200 godina, također povezana s dugotrajnim sušama. Navedene su tek nama najpoznatije civilizacije i događaji (Petersen i Haug, 2005: 322).

Sačuvana je predaja i o migracijama predaka Azteka, prema kojoj su oni, zbog suše ili prenapučenosti, morali napustiti svoj matični grad Azthan. Dugo su tražili slobodnu zemlju dok nisu stigli do priobalnih otoka na jezeru Texacoco. Visoko razvijena civilizacija Maja dosegnula je vrhunce tijekom svoga »klasičnoga razdoblja« (250. - 950. godine n. e.). Oko 750. počela se urušavati i Maje napuštaju svoja gusto naseljena urbana središta, što su arheolozi nazvali »klasičnim konačnim slomom«. Postavljene su, ali ne i šire prihvaćene različite teorije o uzrocima propasti klasične majanske civilizacije: od međusobnih ratova do prodora strane kulture, od epidemije neke bolesti do neodrživosti gospodarstva na monokulturi kukuruza. U novije vrijeme sve više nalaza istraživača govore $u$ prilog tezi da je krajem klasičnoga razdoblja došlo do neočekivanih klimatskih promjena, ponajprije suše.

Čini se da su rani istraživači migracijskih studija imali dosta toga u vidu kad su, gotovo neizostavno, prirodni okoliš smatrali važnom odrednicom 
ljudskoga kretanja u prostoru. Valja početi s F. Ratzelom, koji je, prema Durkheimu (1899, prema Piguet, 2013), položio temelje opće teorije migracija. Misli se na Ratzelovu Antropogeografiju (1882) u duhu vladajućega pogleda na svijet krajem 19. stoljeća, gdje je zacrtao determinističku paradigmu u tadašnjoj naturalistički orijentiranoj geografiji. ${ }^{2}$ Istaknutiji i najpoznatiji utemeljivač migracijskih studija E. G. Ravenstein (1891, prema Piguet, 2013) bio je uvjeren u izuzetnu važnost prirodnoga okoliša za prostorno kretanje ljudi, a među svojim »migracijskim zakonima« Ravenstein (1889, prema Piguet, 2013) nije zaboravio spomenuti »neugodnu klimu«, koja proizvodi migracijske struje, uz druge važne migracijske čimbenike (ekonomski motivi, loši i tlačiteljski zakoni, veliki porezi i dr.). Vjerojatno upravo najistaknutiji predstavnik okolišnog determinizma u geografiji E. Huntington (1922, prema Piguet, 2013) najviše je naglašavao utjecaj fizičke okoline na ljudske migracije. On je tvrdio da se propast Rimskoga Carstva može objasniti »barbarskim « invazijama na Europu, koje su pak potaknute klimatskim promjenama, s jedne strane $u$ Istočnoj Aziji, a s druge u Europi, koja je nakon dugoga razdoblja hladnoće postajala toplija i ugodnija za život. Seizmička katastrofa i vulkanske erupcije još su u 19. stoljeću okrivljavane za propast minojske i mikenske civilizacije i, štoviše, za poremećaje u društvima brončanoga doba na tom području.

Napokon, i Piotr Kropotkin (1902, prema Piguet, 2013), koji se svojom tezom o suradnji i međusobnoj pomoći unutar vrsta i među vrstama suprotstavljao vladajućem evolucionizmu kao »ratu svakoga protiv svih «, također je isticao okolišni pritisak kao središnji potisni čimbenik migracija .

Kad se ima u vidu navedena tradicija, pomalo začuđuje (gotovo) potpuno nestajanje tijekom 20. stoljeća svih aspekata okoliša kao čimbenika koji pokreće i kojim se objašnjavaju migracije iz rastućega korpusa migracijske literature. To zanemarivanje okoliša u migracijskim studijama ide od prirodnoga znanstvenika Gregora (1928) preko Tafta (1936), Stoufera (1940) i Isaaca (1947) do neoklasičnih ekonomista Harrisa i Todaroa (1970) (sve reference u rečenici prema Piguet, 2013), pa čak i biheviorističke struje u geografiji (gdje se prirodni fenomeni samo marginalno povezuju s migracijom).

U izuzetke, u stanovitom smislu, možemo uvrstiti W. Petersena (1970). U svojoj složenoj i najrazuđenijoj općoj tipologiji migracija autor među »pet širokih klasa migracija «navodi i primitione migracije. Pritom misli na besciljna kretanja cijelih skupina ljudi u prostoru. Podijelio ih je na »lutanje naroda«

2 U ovom dijelu rada uvelike se oslanjamo na Piguetovu sistematizaciju migracijskih perspektiva spram ekoloških čimbenika te za navedene reference u ovom odlomku vidjeti u Piguet (2013: 148-150). 
(za što u njemačkom jeziku postoji termin Wanderung) i »morska lutanja «, tj. nenamjeravana seljenja oceanima. U sličnom smislu sakupljači prirodnih plodova i lovci (nomadi) ne mogu dugo preživjeti na jednome mjestu, nego moraju »krstariti« (range) po široj okolini. Način života sakupljača i nomada ovisi o kretanju u okolini, a njihove su nastambe samo privremena boravišta. Stoga ne začuđuje da neki australski indigeni narodi uopće nemaju pojam za »dom«, jer nisu sesilni. Ukratko, pod pojmom primitivne migracije mislilo se na pretpovijesne migracije općenito i poslije na nomadstvo, pri čemu prirodna okolina i promjene u njoj uvjetuju, neposredno ili posredno, migracije ljudi, sve dok neka civilizacija ili čovjek kao vrsta ne »ovlada« prirodom, podređujući (prirodnu) okolinu sebi i svojim potrebama, i tako »neutralizira « utjecaj okoline na ljudske migracije - barem na neko razdoblje. Za Petersena su te migracije konzervirajuće, a ne inovirajuće jer je riječ o kretanju u prostoru, da bi se održao, a ne mijenjao postojeći način života. Važno je istaknuti da su okolišni čimbenici, kao primitivni, (i) za Petersena nevažni za moderne ekonomske migracije i sukladno tom pristupu mogao se samo očekivati daljnji pad njihova utjecaja. ${ }^{3}$ Što međutim kada priroda »uzvrati udarac« čovjekovoj nesmotrenoj protuprirodnoj tehnologiji i njezinim (za prirodu štetnim) »nusproduktima« koji narušavaju složenu »ravnotežu « prirodnih sila i procesa i pokreću (nepovratne) promjene u okolini čije posljedice dramatično nagone sve više ljudi na (prisilne) ekomigracije? Ne samo da oznake primitione i konzervirajuće ne odgovaraju više karakteru tih migracija nego je i dovedena u pitanje temeljna konvencionalna razdioba migracija na dobrovoljne i nedobrovoljne.

Obnova interesa za okolišne čimbenike u migracijskim studijama - ali uglavnom bez pozivanja na rane istraživače i njihove doprinose, te isticanje važnosti okoliša i promjena u njemu na migracije ljudi, svakako je razvidna od druge polovine osamdesetih godina 20. stoljeća. Tri međunarodna izvještaja o klimatskim promjenama i drugim aspektima promjena okoliša pokrenula su svjetsku debatu o važnosti tih pojava za pojedine zemlje, regije i svijet u cjelini, s pogledima u budućnost. Prvi izvještaj pripremljen je za United Nations Environmental Programme (UNEP), drugi za Worldwatch Institute i treći za Intergovernmental Panel on Climate Change (IPCC). U prvom izvještaju IPCC-a iz 1990. jasno je ustanovljeno da bi najveći pojedinačan učinak klimatske promjene mogao biti baš na ljudsku migraciju,

Neki istraživači ne slažu se u ocjeni da su (najranije) ekomigracije eminentno konzervativni čimbenici, nego upravo suprotno, ističu da su ljudske migracije od davnina pokretač društvenih promjena i, štoviše, razvoja (Manning, 2008: 2, 10) jer navode migrante na nove izazove, posebno u susretima s domicilnim grupama. 
s milijunima ljudi raseljenih zbog obalne erozije, poplava i poremećaja u poljoprivredi. Sredinom toga desetljeća ponavljale su se procjene o nekih 25 milijuna ljudi prisiljenih na napuštanje svojih domova izazvano ozbiljnim okolišnim pritiscima, uključujući zagađenje, degradaciju zemlje, suše i prirodne katastrofe. Štoviše, tvrdilo se da je broj »okolišnih izbjeglica «nadmašio sve registrirane ratne i političke izbjeglice zajedno (Brown, 2008: 11-12).

Jedno od objašnjenja obnovljenog interesa za promjenu u okolišu neki teoretičari vide u kraju Hladnoga rata, čime je svjetska pozornost skrenuta od nadmetanja supersila prema okolišu kao potencijalnom uzroku sukoba i prisilnih migracija kao novoj temi za istraživače sukobâ i sigurnosti. "Sekuritizacijom « su zaštitnici okoliša i drugi zainteresirani mogli problem klimatskih promjena lakše postaviti kao međunarodnu i globalnu agendu na utjecajne forume političkoga odlučivanja (Kolmannskog, 2008: 9).

Peti ocjenski izvještaj (assessment report) IPCC-a (Climate Change..., 2014) jasno utvrđuje da se globalno zatopljenje ubrzava, za što su ljudi neposredno odgovorni. Valja očekivati da će klimatske promjene imati znatne učinke na okoliš, ponajprije u zemljama u razvoju. To povratno može biti okidač sukoba i raseljavanja ljudi. Siromašno stanovništvo u tim društvima osobito je ranjivo na promjene $\mathrm{u}$ okolišu, a $\mathrm{k}$ tome je, zbog siromaštva i maloga socijalnoga kapitala, teško pokretljivo. Da stvar bude za njih gora, štetne klimatske promjene samo mogu pogoršati njihovu socijalnu situaciju. Zbog svega toga glavnina prisilnih migracija i sukoba povezanih s klimatskim promjenama vrlo će vjerojatno ostati u okvirima zemalja podrijetla ili u susjednim zemljama njihove regije (Kolmannskog, 2008: 4-6).

U samo dva desetljeća znanost o klimi privukla je trijumfalnu pozornost politike na svim razinama odlučivanja te postala jednim od ključnih pitanja nacionalne, regionalne i globalne sigurnosti. Ne začuđuje onda da je Vijeće sigurnosti Ujedinjenih naroda već 2007. održalo svoju prvu raspravu o učincima klimatskih promjena. Sve je to potaknulo veću pozornost društvenih znanstvenika prema klimatskim promjenama i njihovim društvenim posljedicama, ponajprije (prisilnim) ekomigracijama. No i dalje se ne može tvrditi da su one zadobile istaknuto mjesto u glavnoj struji migracijskih studija, čiji predstavnici, ako se (usputno) i bave ekomigracijama, zauzimaju mahom skeptičku ili minimalističku perspektivu glede društvenih posljedica uzrokovanih promjenama u okolišu i razmjerima očekivanih (prisilnih) preseljenja stanovništva (Piguet, 213: 153-154). 


\section{ODREĐENJE POJMOVA}

Tri su ključna pojma koja u ovoj raspravi treba objasniti i odrediti: okoliš, promjene u okolišu te, najvažnije, karakter ljudskih migracija povezanih s promjenama u okolišu. Tradicionalna ekonomska analiza teži podrazumijevanju jednoobraznoga okolišnoga prostora, dok su u stvarnosti okolišni čimbenici vrlo raznoliki unutar država i među njima (Wood, 2001: 49). Jednostavna, opća definicija okoliša je »totalitet okružujućih uvjeta « (WordNet). ${ }^{4}$

Prema određenju IPCC-a (Climate Change..., 2014), klimatske promjene posljedica su djelovanja niza međusobno povezanih geofizičkih, klimatskih i meteoroloških čimbenika te nastaju kako zbog prirodnih tako i, sve više, zbog ljudskih utjecaja. Ljudski utjecaji ogledaju se u daljnjem povećanju atmosferske koncentracije stakleničkih plinova, porastu prosječne globalne temperature, smanjivanju ledenih i snježnih pokrova, podizanju globalne razine mora te promjeni obrasca i učestalosti padalina. Treba razlikovati tri tipa "promjena u okolišu «, odnosno "promjena okoliša « - što upotrebljavamo kao sinonime jer su to međusobno uvjetovani procesi koje je teško razlučiti ${ }^{5}$ - kao potencijalnih uzročnika i poticatelja raseljavanja i migracija: a) ekstremne vremenske prilike i prirodne katastrofe (izrazito natprosječne hladnoće i topline, sušu i uz nju vezane požare, erupcije vulkana, potrese, poplave, cunamije i olujne vjetrove /poput orkana, uragana, tajfuna i tornada/), b) ekološku neravnotežu i degradaciju uzrokovanu ljudskim (tehnološkim) djelovanjem u prirodi (deforestacija, erozija, iscrpljivanje tla i dezertifikacija, potapanje i tonjenje obalnog i otočnog tla zbog porasta razine mora, zagađenje vode, tla i zraka) i c) tehnološke katastrofe (industrijske nesreće i onečišćenja, atomske i nuklearne havarije, uništavanje okoliša zbog razvojnih projekata). ${ }^{6}$ Slično toj tipologiji, ekomigracije ${ }^{7}$ se mogu podijeliti na tri uzročne kategorije: a) »prirodne« katastrofe (primjerice potres

${ }_{4}$ WordNet: A Lexical Database for English, http://wordnet.princeton.edu (08. 08. 2014.).

5 Naravno, ne misli se na sve promjene u okolišu, nego upravo na štetne, jer neke mogu učiniti neko područje privlačnim odredištem za (eko)migrante. Zbog jednostavnosti oznaku »štetne « podrazumijevamo, ali izostavljamo iz ove sintagme, pa dalje govorimo o "promjenama okoliša « ili »promjenama u okolišu«.

6 Ovdje kao ključni i zbirni pojam upotrebljavamo »promjene u okolišu«, odnosno »promjene okoliša«, pod čime mislimo na sveukupnost promjena u prirodnom i društvenom okolišu na planetu Zemlji (lokalno i globalno) koje su izazvane prirodnim (geofizičkim, klimatskim, ekološkim i/ili biološkim) procesima te ljudskim utjecajem. U tom su smislu »klimatske promjene« niži, podređeni pojam. Osim toga engleski termin environmental prevodimo kao pridjev »okolišni«.

7 Ekomigracije ovdje shvaćamo u širem smislu migracija izazvanih ili uvjetovanih promjenama okoliša, dakle kao sinonim. 
u Kobeu ili poplava rijeke Yangtze 1995.), b) »urbanoindustrijske katastrofe« (poput Černobila ili Bhopala) i c) iskorištavanje i degradacija resursa (Wood, 2001: 50).

Sve te promjene različite su po učestalosti pojavljivanja, intenzitetu pojave, trajanju i stupnju u kojem utječu na ekosustave i biosferu, pa time i na ljudska društva. Iako su prirodne katastrofe prisutne od pamtivijeka, čini se kako su poneke danas ipak učestalije, a projekcije trendova IPCC-a (Climate Change..., 2014) i drugih specijaliziranih institucija i organizacija govore $\mathrm{u}$ prilog tome kako će se broj i intenzitet takvih događaja u budućnosti povećati. Oni često nastupaju brzo i iznenadno, zbog čega je odgovarajuća priprema ugroženog stanovništva, uključujući pravovremenu evakuaciju ili preseljenje, uglavnom nedovoljno učinkovita. Naposljetku, kad je riječ o raseljavanju, migracijama i migrantima, uvjetovanim (neposredno ili posredno) promjenama $\mathrm{u}$ okolišu, $\mathrm{u}$ akademskom i medijskom diskursu danas možemo sresti nekoliko termina koji se dijelom preklapaju, a odnose se na migracijsku problematiku kojom se ovdje bavimo (Faist i Schade, 2013). Tako se govori o okolišnoj (environmental) migraciji, migraciji potaknutoj (induced) klimatskim promjenama, te s tim u vezi o ekološkim ili okolišnim izbjeglicama, klimatskim (climate-change) migrantima i okolišno pokrenutim (induced) prisilnim migrantima, odnosno ekološkim izbjeglicama i raseljenicima. Glavni problem definiranja migracija povezanih sa štetnim promjenama u okolišu leži u teškoćama izdvajanja okolišnih čimbenika od ostalih pokretača (drivers) migracija. Druga važna zapreka proizlazi iz nejasnih granica između dobrovoljnih i prisilnih migracija. Zapravo, raseljenja stanovništva izazvana klimatskim i vremenskim katastrofama, kao što su potresi i poplave, mahom jesu prisilna, dok se to za preseljenja uvjetovana postupnim i kumulativnim čimbenicima degradacije okoliša (kao što je širenje pustinje) ne može jednoznačno (u)tvrditi. K tome, neke štetne promjene u okolišu mogu samo pogoršati siromaštvo i teško održive životne uvjete ljudi na nekim nerazvijenim područjima te se stoga ne mogu smatrati isključivim, pa ni najvažnijim uzrokom njihovih migracija (Dun i Gemenne, 2008: 10).

$\mathrm{U}$ početku uvođenja problematike suvremenih migracija $\mathrm{u}$ vezi s promjenama u okolišu dominirao je pojam »klimatskih « odnosno »okolišnih « (environmental) izbjeglica, ali je ubrzo naišao na žestoku kritiku i protivljenja te ga je s vremenom većina istraživača odbacila kao neprimjeren i neprovediv (Castles, 2011: 417). Naravno, nije riječ o semantičkom sporu, nego o pitanju karaktera tih migracija i migranata (prisilni naspram dobrovoljnih), a time i o pravima tih migranata i obvezama međunarodne zajednice 
(s obzirom na međunarodno izbjegličko pravo). »Smatra se da su okolišni migranti oni pojedinci, zajednice i društva koji se odlučuju na migraciju, ili su prisiljeni na nju, kao posljedicu štetnih okolišnih i klimatskih čimbenika« (Morton, Boncour i Laczko, 2008: 5).

Najpoznatiju definiciju »okolišnih izbjeglica« skovao je El-Hinnawi: »ljudi koji su bili prisiljeni napustiti svoje uobičajeno obitavalište, privremeno ili trajno, zbog nesumnjivog narušavanja okoliša (uvjetovanog prirodnim ciklusima ili/i djelovanjem ljudi), koje ugrožava njihov opstanak i/ili pogađa kvalitetu njihova načina života. Pod 'narušavanjem' [disruption] okoliša u ovoj se definiciji misli na bilo koje fizičke, kemijske i/ili biološke promjene u ekosustavu (ili 'bazi resursa') koje ga čine, privremeno ili trajno, neprikladnim za održavanje ljudskog života« (El-Hinnawi, 1985: 4).

W. Wood (2001: 44,46) ne prihvaća koncept »okolišnih (environmental) izbjeglica«. Između ostaloga, (za njega) termin »okolišni izbjeglica« preuzak je jer okolišni čimbenici, barem djelomično, pogađaju i druge tipove migranata, ne samo izbjeglice. Stoga autor smatra da je korektniji pojam »ekomigranata «, koji za razliku od prvih nisu nužno nasilno raseljeni. Svaka rasprava o ekološkim čimbenicima migracija Trećega svijeta mora se smjestiti unutar nekog ekonomskoga i političkoga konteksta. Siromaštvo i neodrživi životni uvjeti iznad svega tjeraju ekomigrante, bilo u gradska središta u zemlji podrijetla, bilo preko njezinih granica. »Svaka je migracija složeni proces, koji se može jedino razumjeti unutar konteksta socioekonomskih, kulturnih, političkih i okolišnih poveznica između mjesta podrijetla i odredišta «(Wood, 2001: 53). Okolišni čimbenici jedni su od pokretača migracija, ali ni migranti nisu pasivan element u novom okolišu, nego ga mijenjaju.

Brown (2008: 13-15) pokušao je predložiti kompromis terminom »prisilni klimatski migranti«, ali čini se da time nije ublažio postojeće kontroverzije, nego je samo otvorio još jednu konceptualnu i pravnu nejasnoću. Ovdje samo upozoravamo na oštro razilaženje u vezi s karakterom okolišnih migracija i migranata te navodimo dio argumentacije osobito kritičara pojma klimatskih ili okolišnih izbjeglica, ali ne ulazimo sustavnije u tu debatu i stoga ne zauzimamo (otvoreno) vlastito stajalište.

Pojam »okolišne raseljene osobe« (environmentally displaced persons), nasuprot klimatskim izbjeglicama i okolišnim izbjeglicama, nije ovisan o lokaciji i može se upotrijebiti za označivanje unutarnje raseljenih osoba kao i izbjeglica. Međunarodna organizacija za migracije (International Organization for Migration - IOM) je prihvatila široku (radnu) definiciju »okolišnih migranata« kao »osoba ili grupa osoba koji su zbog prinudnih [compelling] razloga izazvanih iznenadnim ili progresivnim promjenama, koje štetno 
pogađaju njihove živote ili životne uvjete, primorani [obliged] napustiti svoje uobičajene domove ili su to izabrali, bilo privremeno ili trajno, i koji se sele unutar svoje zemlje ili u inozemstvo« (Kolmannskog, 2008: 9).

Dugoročni utjecaji klimatskih promjena na prostorna kretanja stanovništva uvelike će regionalno varirati. Pritom će neke globalne promjene okoliša imati sistemski (kao što je fenomen stakleničkih plinova), a druge kumulativni (kao što je uništavanje šuma) učinak na društva. Mnoge bi iznenadila pretpostavka da su danas najmasovnije ekomigracije prema gradovima Trećega svijeta te iz njih dalje preko granica država. Većina ekomigranata migrira i naseljava se u gradska središta unutar svojih zemalja porijekla. Manji dio prelazi u susjedne države $u$ istoj regiji (»migracije Jug-Jug«), dok ih najmanje kreće $u$ migracije na duge razdaljine prema razvijenim zemljama Zapada. Teško bismo pomislili pak da su u Prvom svijetu sve masovniji migracijski tokovi umirovljenika, bilo sezonskoga ili trajnoga karaktera, u krajeve s povoljnijom (umjerenom) klimom (Wood, 2001: 51-52).

Nerazvijena siromašna društva suočena su s težim udarima narušavanja prirodne ravnoteže u okolišu, već i zbog toga jer im nedostaju ekonomska, organizacijska i učinkovita politička infrastruktura za prilagodbu promjenama. Osobito ranjiva područja na siromašnom Jugu male su otočne zemlje u razvoju, sahelski pojas, Bengalski zaljev, sušna područja Južne i Središnje Amerike te sušne regije u Središnjoj Aziji (Morton, Boncour i Laczko, 2008: 6). Nisu, ipak, sve posljedice (eko)migracija negativne. Napuštanje degradiranoga okoliša i poljoprivredno neodrživih područja može biti legitimna strategija nošenja sa štetnim promjenama u izvornom okolišu. ${ }^{8}$

\section{RAZLIČITI POGLEDI NA DRAMATIČNOST OKOLIŠNIH MIGRACIJA}

Sedamdesetih godina 20. stoljeća ustanovljena je oštra podjela između istraživača koji predviđaju sve veće i dramatičnije valove »okolišnih izbjeglica« i onih koji su prema tome skeptični. Prve, koji nastoje izolirati okolišne čimbenike kao glavne pokretačke sile migracija, ponekad nazivaju »alarmatičarima«, a druge, koji dokazuju složenost migracijskih procesa i njihovu višestruku uzročnost, »skepticima«. Alarmatičari obično dolaze iz

Zbog potrebe suradnje i koordinacije raznih međunarodnih organizacija i agencija te znanstvenika i političara na području uništavanja okoliša i okolišnih migracija, osnovana je 2008. u Münchenu krovna organizacija Climate Change, Environment and Migration Alliance (CCEMA). Osnivači su United Nations University (UNU), International Organization for Migration (IOM), United Nations Environment Programme (UNEP) i Munich Re Foundation (MRF). 
studija okoliša, katastrofa i sukoba, a skeptici uglavnom iz migracijskih i izbjegličkih studija (Gemenne, 2011b). Ponekad se spominju i »pragmatičari«, koji zauzimaju stanovitu srednju poziciju (Piguet, 2013: 154-156).

\section{Alarmantno-katastrofična perspektiva}

Njen je začetnik oxfordski ekološki znanstvenik Norman Myers, koji je devedesetih godina 20. stoljeća predviđao prvo sto pedeset, a potom dvjesto milijuna »okolišnih izbjeglica«, zbog kojih čovječanstvu prijeti jedna od najvećih kriza našega vremena. Tvrdio je da će većina migracija u budućnosti biti potaknuta prirodnim katastrofama ili neravnotežom u okolišu (Myers i Kent, 1995; Myers, 2002). Ta je projekcija »okolišnih izbjeglica« za 21. stoljeće postala široko prihvaćena i navođena, kako u akademskim krugovima tako i u medijima. Svoje je procjene, štoviše, smatrao »opreznim i konzervativnim« jer njima nije obuhvaćeno nekih 135 milijuna ljudi ugroženih dezertifikacijom te čak 550 milijuna onih koji pate od sve većeg nedostatka vode (Myers, 2002: 610). Najave ekoizbjegličke katastrofe dramatizirane su u naslovima izvještaja, knjiga, rasprava i medijskih prikaza. Myersovi istomišljenici prepoznaju se po upotrebi slikovitih hidroloških metafora dok govore o budućim klimatskim ili okolišnim migrantima, kao što su bujice, struje, plime i valovi. Na tom je tragu i primjerice izvještaj za Norveški izbjeglički savjet Future floods of refugees: A comment on climate change, conflict and forced migration (Kolmannskog, 2008) i svakako noviji članak Biermanna i Boasa (2010), koji predlažu sustav globalnog upravljanja u zaštiti klimatskih izbjeglica.

Pozornost šire javnosti (bogatih država) privukle su predodžbe o »rijekama« ekoizbjeglica s globalnoga Juga. Myersove alarmantne prognoze klimatskih promjena i s njima povezanih prisilnih migracija potaknule su znanstvene rasprave, međunarodne konferencije i publikacije. No prava dramatizacija rastućih opasnosti zbog nadolazećih raznovrsnih ekomigracija počela je petnaest godina poslije, nakon pojave autoritativnoga kritičkog prikaza ekonomskih posljedica globalnog zatopljenja sir Nicholasa Sterna, koji piše: „Sve veći nedostatak resursa, širenje pustinje i podizanje razine mora mogli bi natjerati mnoge milijune ljudi na migracije « (Stern, 2007: 128). Takva zastrašujuća očekivanja širile su civilne udruge, a masovni mediji pretvorili su ih u udarne naslove. Stern je svojim izvještajem alarmirao svjetsku javnost kako će veliki dijelovi supsaharske Afrike te središnje i jugoistočne Azije trpjeti najviše od budućih promjena u okolišu. Ta područja odlikuju populacijska prenapučenost i velika okolišna ranjivost te istovremeno najslabiji institucionalni kapaciteti za suočavanje s tim promje- 
nama, njihovo ublažavanje ili prilagodbu njihovim posljedicama. Pretežito poljoprivredna gospodarstva afričkoga kontinenta kao i zaposlenost većine radne snage u supsaharskoj Africi u ruralnim sektoru imaju za posljedicu nisku razinu otpornosti na klimatske krajnosti te veliku ovisnost o okolišu za svoje preživljavanje. Relativno loša poljoprivredna produktivnost značila bi dodatan stres za sigurnost proizvodnje hrane, a većina afričkih zemalja već je ionako u stanju povećanoga okolišnog stresa uzrokovanog pomanjkanjem vode. Stern se slaže da je vjerojatno kako bi do 2050. moglo biti više od dvjesto milijuna raseljenih zbog promjena u okolišu.

Pozivajući se na podatke istraživačkih centara i agencija, Međunarodna federacija društava Crvenoga križa i Crvenog polumjeseca (International Federation of Red Cross and Red Crescent Societies - IFRC/RCS) procijenila je da je u svijetu tijekom devedesetih (1992. - 2001.) ukupno čak 2,36 milijardi ljudi bilo pod utjecajem nekog oblika okolišne katastrofe, njome ugroženo ili pogođeno. Od 2002. do 2011. taj se broj povećao za 14\% i popeo na 2,64 milijarde ljudi koji su bili pogođeni katastrofama (Zetter, 2012: 283), što se pripisuje prije svega povećanju klimatskih, posebice »hidrometeoroloških «, prirodnih nepogoda i katastrofa. ${ }^{9}$ Izvješće Centra za praćenje interne raseljenosti Norveškog vijeća za izbjeglice (Internal Displacement Monitoring Centre, Norwegian Refugee Council - IDMC/NRC) (Yonetani, 2014) procjenjuje da je u 2001. prvi put broj osoba u svijetu koje su raseljene zbog okolišnih razloga premašio broj osoba raseljenih zbog rata i situacija općeg nasilja. Izvješće vjersko-humanitarne organizacije Christian Aid ${ }^{10}$ alarmira da bi intenzitet broja raseljenih zbog promjena u okolišu do 2050. mogao »destabilizirati cijele regije u kojima sve očajnije stanovništvo vodi utrku za oskudne zalihe hrane i vode«. Ovdje nalazimo projekciju po kojoj se do 2050. može očekivati raseljavanje nekih 250 milijuna ljudi zbog klimatskih pogoršanja (kao što su suše, poplave i uragani). Njima bi se moglo pridružiti 645 milijuna raseljenika zbog razvojnih projekata, poput izgradnje brana. No istovremeno očekuju da će samo pet milijuna »klimatskih izbjeglica« uspjeti prijeći međunarodne granice.

Neki znanstvenici zainteresirali su pripadnike političkih elita upozoravajući na okolišne migracije kao sve važnije »sigurnosno pitanje« u nacionalnim, regionalnim i globalnim političkim odnosima. Tako Nordås i Gleditsch (2007: 5) naglašavaju kako promjene u okolišu smanjuju dostupnost

9 Godišnje procjene broja ljudi pogođenih nekim oblikom prirodne nepogode i katastrofe vidi u Guha-Sapir, Hoyois i Below (2014) ili na http://www.emdat.be/.

10 Human Tide: the Real Migration Crisis. A Christian Aid Report (2007), http://www.christianaid.org.uk/images/human-tide.pdf (12. 12. 2010.). 
osnovnih sredstava za život, primarno hrane i vode, ali i drugih, primjerice ogrjeva. Treba znati da će se većina ljudi pogođenih promjenama u svom okolišu ponajprije pokušati njima prilagoditi, ostajući dakle na istome mjestu odnosno lokalitetu u širem smislu. Prilagodba i otpornost na promjenu ovise o njihovim sposobnostima i dostupnim (alternativnim) resursima. Konačno, ljudi mogu biti prisiljeni da napuste to područje. Taj proces nije uvijek linearan i ljudi se u različitim fazama mogu odlučiti za različite strategije. No i na području preseljenja može vladati oskudica sredstava za život, što je čest slučaj jer se najveći dio prekograničnog preseljenja odvija u siromašnim regijama. To (nužno) vodi borbi za preživljavanje te sukobima zbog prostora i resursa, čime se (p)održava spirala međusobnog nasilja i novih pritisaka za raseljavanje i migracije.

\section{Skeptično-kritička perspektiva}

Skeptici su odmah odgovorili odbacujući i sam pojam »okolišnih izbjeglica«. Temelje takva pristupa položili su antropolog Gaim Kibreab (1997) i geograf Richard Black (2001), a prihvatio ga je u nešto blažem obliku i Stephen Castles (2011). Zapravo, na migraciju ne treba gledati kao na tragediju po sebi, nego upravo suprotno, kao na oblik proaktivne prilagodbe (Piguet, 2013: 155). K tome, nije svaka migracija povezana s promjenama u okolišu nužno prisilna migracija. Migracija je jedna od najstarijih strategija nošenja s promjenama u okolišu (Kolmannskog, 2008: 11). Treba imati u vidu da dramatiziranje nadolazeće »plime« okolišnih izbjeglica služi vladama bogatih zapadnih zemalja u legitimiziranju njihove politike zatvorenih granica, već prije potaknute rastućim domaćim antiimigrantskim raspoloženjem. Skeptici ističu da »alarmistički neodeterminizam « svoje zastupnike navodi na mehanicističko shvaćanje odnosa uzroka (pogoršanje u okolišu) i posljedica (raseljavanje i migracije) bez uzimanja u obzir lokalnih osobitosti, povijesti ili kulture.

Gemenne (2011a: 42-43) upozorava na metodološku nepouzdanost na kojoj počivaju alarmističke prognoze o razmjerima okolišnih raseljavanja i migracija. ${ }^{11}$ Alarmisti nisu uspjeli (za sada) nepobitno dokazati neposrednu povezanost okolišnih čimbenika i migracija - što s druge strane ne znači da u bližoj ili daljoj budućnosti promjene u okolišu i njihove posljedice na migracije ljudi konačno neće krenuti u smjeru njihovih scenarija, iako sa »zao-

11 Riječ je o jednostavnoj ekstrapolaciji, to jest utvrđivanju postojećih trendova (u našem slučaju rasta broja okolišnih migranata) te njihovu produženju u budućnost. Što je odabrana »točka« u budućnosti dalja, vjerojatnije su pogreške predviđanja jer se povećavaju izgledi za djelovanje interferirajućih čimbenika, koje može biti u neskladu s postojećim trendom. 
statkom u fazi«. Ne može im se međutim poreći zasluga za senzibiliziranje svjetske javnosti i političkih čimbenika na promjene u okolišu i njihove (moguće) društvene posljedice, posebno okolišne migracije ljudi.

Denaturalizacija društvenih znanosti, emancipacija od prirode shvaćene kao »vanjski« čimbenik, posebno u našem kontekstu sociologije i socijalne geografije, bio je zacrtani put njihova »znanstvenog « razvoja i afirmacije do kraja 20. stoljeća. U tom su duhu ignorirali i socijalnu i političku ekologiju, čak i kada su odbacivali (ekološki) determinizam. Ipak, zahvaljujući uvelike dramatičnim promjenama u okolišu i njihovim posljedicama na ljude i njihove zajednice, došlo je do "povratka prirodi « u migracijskim studijama, mada još uvijek opreznog i neodlučnog (Piguet, 2013: 156-159). Iz nove perspektive »možemo okoliš smatrati jednim od čimbenika koji uvjetuju društveni proces migracija, premda takav koji je u međusobnom djelovanju s mnogim drugima, uključujući odnose moći, klasne strukture, ekonomske nejednakosti, kolonijalno nasljeđe, kulturne i vjerske osobitosti, političku organizaciju i rodne odnose. Uza sve te druge dimenzije okoliš možemo shvatiti ne kao nešto izvanjsko društvima, nego kao proizvod objektivnih, mjerljivih promjena te subjektivnih načina na koje društva daju smisao tim promjenama« (Piguet, 2013: 157).

\section{RASELJAVANJE I MIGRACIJE PREMA TIPOVIMA PROMJENA U OKOLIŠU}

\section{Ekstremne vremenske prilike i prirodne katastrofe}

Pod tim određenjem misli se prije svega na pojedinačne klimatske, geološke, meteorološke i hidrometeorološke pojave, koje su često iznenadne i razorne, ali uglavnom kratkotrajne. U najboljem slučaju, ugroženo lokalno stanovništvo može se pripremiti za katastrofu tako da se skloni u sigurnije objekte ili (privremeno) evakuira. Nepogode izazvane »ekstremnim vremenskim prilikama « čine većinu svih promjena u okolišu, a poplave i suše generiraju najviše okolišnih migracija i raseljavanja u svijetu.

Izvješća Međuvladinog panela o klimatskim promjenama (IPCC-a) naglašavaju kako se suvremene klimatske promjene razlikuju od prirodne klimatske promjenljivosti jer dobrim dijelom proizlaze iz ljudskih aktivnosti koje mijenjaju Zemljin klimatski sustav (Climate Change...,, 2014). Od druge polovine 18. stoljeća kroz industrijalizaciju i sve veću upotrebu fosilnih ugljikovodičnih goriva značajno se povećava utjecaj čovjeka na klimu i okoliš. Izgaranje tih goriva dovodi do promjene u kemijskom sastavu atmosfere, čime se stvara poznati »efekt staklenika«, što pogoduje globalnom zato- 
pljenju. Stoga su danas ekstremne vremenske prilike i prirodne nepogode prije svega posljedica visoke koncentracije stakleničkih plinova $u$ atmosferi, kao viška energije koji se manifestira kroz ekstremne klimatske događaje i procese.

Ukratko navodimo poznatije i dramatičnije primjere. Samo je na Filipinima tijekom 2013. zbog dvaju tropskih tajfuna i jednog potresa bilo privremeno raseljeno 6,15 milijuna ljudi (Yonetani, 2014: 8). Monsunske poplave i odroni tla 2011. u Bangladešu natjerali su nekih 1,5 milijuna ljudi na raseljavanje i smještaj u prihvatne centre, slične izbjegličkim kampovima (Gemenne, Brücker i Ionesco, 2012: 63). Jedan od najrazornijih olujnih vjetrova na sjevernoameričkom tlu uragan Katrina pogodio je u kolovozu 2005. južne dijelove SAD-a. Uragan je uz ljudske žrtve uzrokovao i trenutačnu raseljenost više od 1,5 milijuna ljudi. To je istodobno i eklatantan primjer nejednakih prilika za raseljavanje i migracije siromašnih i bogatih. U razvijenom SAD- $u$, barem $u$ početku te vremenske katastrofe, 70.000 siromašnih stanovnika New Orleansa, mahom Afroamerikanaca, nije imalo mogućnosti ni sredstva za napuštanje svojih domova (Gemenne, 2010). Jedna od najrazornijih suvremenih prirodnih katastrofa, potres u podmorju kod obale Sumatre u prosincu 2004. i cunami nakon njega, prouzročila je ljudske žrtve i nezamislivu materijalnu štetu. Uz 230.000 poginulih u razornome plimnom valu, oko 1,7 milijuna ljudi bilo je privremeno evakuirano i raseljeno iz svojih obitavališta (Rofi, Doocy i Robinson, 2006). Cunamiji, visoki plimni valovi, mogu nastati i kao rezultat erupcije vulkana na morskom dnu.

Prema World Disaster Report 2012 (Zetter, 2012), raseljavanje stanovništva u svijetu pokrenuto klimatskim i vremenskim katastrofama u pojedinim godinama od 2008. do 2011. premašilo je po opsegu raseljavanja zbog etničkih, vjerskih i drugih sukoba. ${ }^{12}$ Očigledna je tendencija sve bržega rasta raseljavanja čiji su glavni pokretači prirodne katastrofe, a to je samo dio ukupnih ekomigracija.

Oko pola milijarde ljudi u svijetu izloženo je velikim neizvjesnim rizicima od prirodnih katastrofa jer su nastanjeni na relativno maloj udaljenosti od sedamdesetak i danas aktivnih vulkana (Doocy i sur., 2013). Suša je pak

12 Do kraja 2012. u svijetu je bilo 45,2 milijuna prisilno raseljenih zbog političkog i vojnog nasilja, progona, sukoba i kršenja ljudskih prava, od čega čak 28,8 milijuna interno raseljenih osoba (UNHCR, 2014: 5). Istovremeno je u 2012. bilo 32,4 milijuna prisilnih migranata koji su raseljeni iz svojih domova zbog rizika od iznenadnih katastrofa i prirodnih nepogoda ili pod njihovim utjecajem, s time da ih je u 2012. bilo najviše, čak 42,3 milijuna (Yonetani, 2014: 7). Podaci za 2013. govore o 21,9 milijuna ljudi raseljenih zbog prirodnih nepogoda i katastrofa, dok se broj raseljenih zbog političkih razloga popeo na 51,2 milijuna (UNHCR, 2014: 2). 
najučestaliji oblik krajnje vremenske nepogode koja pogađa područja Sahare i zemalja Sahela. Prema nalazima Browna i Crawforda (2009), suše su u Africi između 1975. i 2002. činile 31\% prirodnih katastrofa, a poplave $26 \%$. Odnosno, izraženo na drugi način, gotovo trećina stanovništva Afrike živi u regijama ugroženim sušom, a svakom četvrtom Afrikancu nije stalno dostupna pitka voda. Posljedice suše naročito su teške u zemljama Roga Afrike i u regiji Darfur u zapadnom Sudanu. ${ }^{13}$

\section{Ekološka neravnoteža i uništavanje okoliša uzrokovani ljudskim djelovanjem}

Dok se na iznenadne vremenske nepogode ljudi teško mogu (dugoročno) pripremati, reakcija na postupno narušavanje okoliša može biti dugoročna i strateška (Boano, Zetter i Morris, 2008). Ta vrsta narušavanja okoliša globalna je pojava, ali se (i) s njom teže nose siromašne regije svijeta, posebno osjetljive na posljedice globalnog zatopljenja i ljudske intervencije u prirodna staništa (zemlje Sahela i Roga Afrike te Jugoistočne Azije). Deforestacija i dezertifikacija posljedica su ponajprije ljudskog djelovanja, ali djelomice i prirodnih procesa. ${ }^{14}$ Prva je najčešće povezana s razvojnim projektima i krčenjem šuma za dobivanje novoga agrikulturnog tla i/ili iskorištavanje šumskih resursa, ponajprije drvnog fonda. Takvo djelovanje vodi do daljnjeg pojačavanja učinaka globalnog zatopljenja, a vrlo je izgledno da će utjecati i na nastavak ruralno-urbanih nedobrovoljnih migracija i napuštanje tradicionalnih obitavališta indigenih populacija, naročito u južnoazijskim i južnoameričkim područjima (Carr, 2009).

Dezertifikacija se ne odnosi samo na "širenje pustinje « nego i na razne oblike smanjenja plodnosti tla i narušavanja kopnenih ekosustava. Prema procjenama Agencije za provođenje Konvencije UN-a za borbu protiv dezertifikacije (UN Convention to Combat Desertification), suha područja

13 Zbog dugotrajne suše koja je zahvatila Darfur došlo je do prvih sukoba krajem sedamdesetih godina 20. stoljeća između etničkih skupina afričkih poljoprivrednika i arapskih stočara. Suša je dovela do nedostatka pitke vode za ljude i stočni fond, kao i vode za navodnjavanje obradivih površina. Posljedično je to značilo manje prinose hrane, kako za stočare tako i za ratare. Dok su neki promatrači te sukobe odmah označili međuetničkima, Abbott (2008: 5) nalazi kako su u njihovoj pozadini upravo okolišni razlozi i, štoviše, provokativno izjavljuje kako smo tada zapravo svjedočili "prvome klimatskom ratu«.

14 Poznat je fenomen »zdjele s prašinom « (Dust Bowl) tridesetih godina 20. stoljeća, kako je nazvana okolišna katastrofa na američkome Srednjem zapadu, ubrzana sušom i pogoršana lošim iskorištavanjem zemlje, koja je natjerala na raseljavanje 3,5 milijuna ljudi iz područja »velikih ravnica" (de Sherbinin, Warner and Ehrhart, 2011: 64). Oko šezdeset posto stanovništva - exodusters, kako su nazvani, raselilo se prvo na druga poljoprivredna područja te poslije u gradove. 
(drylands) zauzimaju čak $41 \%$ Zemljine površine i na njima živi više od dvije milijarde ljudi (Adeel i sur., 2005: 1) te daljnja deforestacija, dezertifikacija i erozija tla ugrožavaju njihova obitavališta, čime postaju pokretači migracija i raseljavanja.

S druge strane, globalno zatopljenje uzrokuje ubrzano topljenje snježnog i ledenog pokrova, što pridonosi podizanju razine oceana i mora, a to prijeti poplavljivanjem litorarnih pojasa i riječnih ušća te posebno niskih malih otoka-država u Tihome i Indijskom oceanu (Kiribatija, Maršalovih otoka, Tokelaua i Tuvalua te Maldiva). To je postalo najpopularnijom ekološkom temom svjetskih medija. Nadmorska visina tih atolnih otoka rijetko prelazi desetak metara u najvišoj točki, što ih čini vrlo osjetljivima na porast razine mora i plimne valove. $\mathrm{K}$ tome su relativno gusto naseljeni, što znači da je veliki broj ljudi na malom prostoru izložen klimatskom i okolišnom stresu i riziku (Barnett, 2001). Istodobno s rastom razine mora suočeni su s ograničenim zalihama pitke vode i zagađivanjem izvora, ponajprije salinizacijom. Te su otočne zajednice među najnerazvijenijima u svijetu (Barnett, 2001: 978) te su (eko)migracijski tokovi pokrenuti (Jäger i sur., 2009).

\section{Tehnološke katastrofe}

Tehnološke katastrofe proizlaze iz okolišno neprimjerene tehnologije ili njezine pogrešne upotrebe ${ }^{15}$ te neposredno ili posredno izazivaju raseljavanja i migracije pogođenog stanovništva. Tako je 1979. oko 144.000 ljudi evakuirano iz središnje Pennsylvanije nakon havarije i pojave radioaktivnog oblaka iz nuklearne elektrane Otok tri milje (Three Mile Island) (Perrow, 2011). Posljedice nuklearne katastrofe u ukrajinskom Černobilu 1986. još su teže, kako u neposrednim ljudskim žrtvama tako i u dugoročnim štetnim učincima radioaktivnoga zračenja stanovništva u užoj i široj okolini. Do danas je evakuirano i raseljeno više od 350.000 lokalnih stanovnika.

Zbog »razvojnih" gospodarskih projekata, ponajprije izgradnje velikih riječnih hidrocentrala i krčenja tropskih šuma, koji dovode do promjena u okolišu (gubitka bioraznolikosti i prirodnih resursa) raseljavaju se (prisilno) razne skupine lokalnoga stanovništva, među kojima su često autohto-

15 Treba ipak imati na umu da su tehnološko uništavanje i ugrožavanje životnih uvjeta u okolišu ponekad izazvani drugim (prirodnim) čimbenicima. Dobar je primjer nuklearna katastrofa u Fukushimi (ožujak 2011.), do koje je došlo zbog dviju ekstremnih prirodnih nepogoda. Potres u pacifičkom podmorju izazvao je veliki plimni val (cunami), da bi njegovi ogromni i razorni valovi provalili u samu elektranu, uništili njezin sustav hlađenja i tako izazvali nuklearnu havariju s ljudskim žrtvama i raseljenjem cjelokupnoga lokalnog stanovništva - 185.000 ljudi, prema: CNN (2014). 2011 Japan Earthquake - Tsunami Fast Facts, u: CNN Library, July 11, 2014 - Updated, http://edition.cnn.com/2013/07/17/world/ asia/japan-earthquake---tsunami-fast-facts/ (28. 08. 2014.). 
ne zajednice, koje time gube mogućnost održavanja tradicionalnoga načina života i kulture (Bates, 2002). Drastičan je primjer »razvojnih« raseljenika i (prisilnih) migranata izgradnja brane Tri klanca (Three Gorges Dam) na rijeci Yangtze u središnjoj Kini, kada je potopljeno trinaest gradova, oko sto pedeset naselja i više od tisuću sela. Od početka radova 1994. do dovršenja 2006. raseljeno je oko 1,25 milijuna ljudi, a posredno je pogođeno još nekih 400.000 u okolici (Xu, Tan i Yang, 2013). ${ }^{16}$

\section{ZAKLJUČAK}

Međunarodna zajednica i posebno njezine institucije i organizacije na ovom području vjerojatno sa zakašnjenjem priznaju da uništavanje okoliša i klimatske promjene ako ne neposredno, onda posredno navode sve više ljudi na raseljavanje s ugroženih područja. Pod poticateljima okolišnih migracija ponajprije se misli na iznenadne i dramatične klimatske katastrofe, a rjeđe na postupno narušavanje okolišne ravnoteže, odnosno gospodarske i društvene održivosti u nekom prostoru. K tome (eko)migracije mogu i same pridonijeti daljnjem narušavanju održivosti užega ili širega ljudskoga okoliša (Barnett i Chamberlain, 2010: 51).

Koliko su procjene o brojnosti budućih prisilnih migranata, natjeranih na preseljenje zbog klimatskih promjena, (još uvijek) neprecizne i nesigurne, govori i njihov raspon, primjerice za razdoblje do 2050., koji se kreće od dvjesto milijuna do milijarde ljudi. »Te procjene temelje se na ocjenama izloženosti riziku u širokim razmjerima, a ne na sistematskim nalazima o osjetljivosti migracija na okolišne promjene ili na stupanj do kojega prilagodba može smanjiti klimatske učinke« (Barnett i Chamberlain, 2010: 51-52). Zbog toga i drugih epistemoloških poteškoća takva predviđanja trebaju se uzeti oprezno i uvjetno.

Valja imati na umu da su rasprave o učincima promjena u okolišu na razmještaj stanovništva ponajprije usmjerene na dramatiziranje potencijalnih ekomigracija iz globalnoga Juga prema globalnom Sjeveru, premda je uistinu riječ o izrazito malom dijelu takvih migranata. U svemu tome ostaje potpuno zanemareno pitanje što s onima koji (nedobrovoljno) ostaju na ugroženim i ekološki devastiranim područjima jer su odveć siromašni i apatični da bi se pokrenuli, a neki su suočeni i s teškim preprekama za migracije na udaljena odredišta, kao što su otočani na velikim pacifičkim prostranstvima.

${ }_{16}$ Kineska vlada organizirala je preseljenje te osigurala stanovitu financijsku i pravnu pomoć, ali mnogi su postali nesretni zbog neželjenih promjena u okolini i (novom) načinu života. 
Skeptici, srećom, mogu (za sada) dokazivati da se zastrašujući crni scenariji o sve snažnijim i nezaustavljivim valovima okolišnih migranata (izbjeglica) ipak nisu ostvarili te da okolišni pokretači ljudskih migracija ne djeluju izolirano, nego u složenim sklopovima ekonomskoga, socijalnog i političkoga (ne)razvoja pojedinih političkih zajednica i cijelih regija. Ipak, oni (kao ni bilo tko drugi) ne mogu, nažalost, uvjerljivo osporiti da samo jedna kataklizmička prirodna katastrofa (kao što je udar meteora u Zemlju) može izazvati uništenje (dijela) čovječanstva i pretvaranje velikih dijelova našeg planeta u beživotna područja. No i bez takvih krajnjih prirodnih poremećaja u ljudskom okolišu, očiti su jasni znakovi upozorenja da se (za čovjeka) održiva ravnoteža u okolišu, u raznim dijelovima svijeta i globalno, sve teže održava, a ne postoji neka (globalna) učinkovita strategija da se ti negativni procesi zaustave ili barem uspore, zbog čega možemo očekivati da će okolišne migracije dobivati na zamahu, a time i na ekonomskoj, političkoj i sigurnosnoj važnosti. ${ }^{17}$ Ako je ova naša (protuprirodna) civilizacija osuđena na propast, okolišni čimbenici, po svemu sudeći, bit će među njezinim grobarima. Da stvar bude još gora, za razliku od propalih antičkih civilizacija, za preživjele više neće biti mjesta na Zemlji.

\section{LITERATURA}

Abbott, C. (2008). An Uncertain Future: Law Enforcement, National Security and Climate Change, u: Oxford Research Group - Fride Comment, February 2008, fride.org/ download/com_law_security_climate_en_feb08.pdf (19.03. 2013.).

Adeel, Z., Safriel, U., Niemeijer, D., White, R. i sur. (2005). Ecosystems and Human Well-being: Desertification Synthesis: a Report of the Millennium Ecosystem Assessment. Washington, D.C.: World Resources Institute.

Barnett, J. (2001). Adapting to Climate Change in Pacific Island Countries: the Problem of Uncertainty, World Development, 29 (6): 977-993, doi: 10.1016/s0305-750x(01)00022-5.

17 Dok dovršavamo ovaj tekst, stižu vijesti (koje su postale više redovite nego izvanredne!) o tajfunu nazvanom Hagupit koji je udario u istočne dijelove filipinskoga otočja i koji, uz olujni vjetar (treće kategorije, što znači da je nešto slabiji od supertajfuna), povlači velike valove i visoku razinu mora. Prva izvješća govore da je izbjeglo oko pola milijuna ljudi, a bit će pogođeno i do pedeset milijuna Filipinaca, odnosno polovina stanovništva te zemlje. Agencija UN-a već je objavila da je riječ o najvećoj mirnodopskoj evakuaciji ljudi na svijetu. Vijesti o klimatskim promjenama, koje, čini se, (re)afirmiraju više »alarmatičare« nago »skeptike«, sustižu jedne druge. Takve primjerice dolaze iz završnice UN-ove Konferencije o klimi iz Lime u prosincu 2014. Glavni tajnik UN-a Ban Ki-moon istaknuo je da »nemamo vremena za gubljenje«. Ostaje međutim oštra podjela između razvijenih i nerazvijenih zemalja, jer jedni traže od drugih da »učine više«. Napokon je i SAD »borbu protiv klimatskih promjena u uvrstio u vrh svojih prioriteta, o čemu svjedoči i iznenadan dolazak na Konferenciju američkoga državnog tajnika Johna Kerryja. 
Barnett, J. i Chamberlain, N. (2010). Migration as Climate Change Adaptation: Implications for the Pacific, u: B. Burson (ur.). Climate Change and Migration: South Pacific Perspectives. Wellington: Institute for Policy Studies, 51-60.

Bates, D. C. (2002). Environmental Refugees? Classifying Human Migrations Caused by Environmental Change, Population and Environment, 23 (5): 465-477.

Biermann F. i Boas, I. (2010). Preparing for a Warmer World: Towards a Global Governance System to Protect Climate Refugees, Global Environmental Politics, 10 (1): 60-88, doi: 10.1162/glep.2010.10.1.60.

Black, R. (2001). Environmental refugees: myth or reality?. Brighton: University of Sussex (UNHCR - New Issues in Refugee Research: Working Paper, 34), http://www.unhcr. org /3ae6a0d00.html (19. 05. 2013.).

Boano, C., Zetter, R. i Morris, T. (2008). Environmentally displaced people: understanding the linkages between environmental change, livelihoods and forced migration. Oxford: Refugee Studies Centre, University of Oxford (Forced Migration Policy Briefing, 1), http:// www.rsc.ox.ac.uk/files/publications/policy-briefing-series/pb1-environmentallydisplaced-people-2008.pdf (09. 03. 2014.).

Brown, O. (2008). Migration and Climate Change. Geneva: International Organization for Migration (Migration Research Series, 31), http://www.iom.cz/files/ Migration_and_ Climate_-Change_IOM_Migration_Research_Series_No_31.pdf (02. 06. 2014.).

Brown, O. i Crawford, A. (2009). Climate Change and Security in Africa: a Study for the Nordic-African Foreign Ministers Meeting, u: International Institute for Sustainable Development, March 2009, http://www.iisd.org/pdf/2009/climate_change_security_ africa.pdf (13. 09. 2014.).

Carr, D. (2009). Population and deforestation: why rural migration matters, Progress in Human Geography, 33 (3): 355-378, doi: 10.1177/0309132508096031.

Castles, S. (2011). Concluding remarks on the climate change-migration nexus, u: E. Piguet, A. Pécoud i P. de Guchteneire (ur.). Migration and Climate Change. Paris Cambridge: UNESCO Publishing - Cambridge University Press, 415-427.

de Sherbinin, A., Warner, K. i Ehrhart, C. (2011). Casualties of Climate Change, Scientific American, 304 (1): 64-67, doi: 10.1038/scientificamerican0111-64.

Doocy, S., Daniels, A., Dooling, S. i Gorokhovich, Y. (2013). The Human Impact of Volcanoes: a Historical Review of Events 1900-2009 and Systematic Literature Review, PLOS Currents Disasters (published online 16 April 2013), doi: 10.1371/ currents.dis.841859091a706efebf8a30f4ed7a1901.

Douglas, K. (2012). Why we did go global?, New Scientist, 2857 (213): 40-41.

Dun, O. i Gemenne, F. (2008). Defining 'environmental migration', Forced Migration Review, 2008 (31): 10-11.

El-Hinnawi, E. (1985). Environmental Refugees. Nairobi: United Nations Environment Programme (UNEP).

Faist, T. i Schade, J. (2013) The Climate-Migration Nexus: A Reorientation, u: T. Faist i J. Schade (ur.). Disentangling Migration and Climate Change: Methodologies, Political Discourses and Human Rights. Dordrecht: Springer, 3-25, doi: 10.1007/978-94-0076208-4_1.

Gemenne, F. (2010) What's in a Name: Social Vulnerabilities and the Refugee Controversy in the Wake of Hurricane Katrina, u: T. Afifi i J. Jäger (ur.). Environment, Forced Migration and Social Vulnerability. Springer, 29-40, doi: 10.1007/978-3-642-12416-7_3. 
Gemenne, F. (2011a). Why the numbers don't add up: a review of estimates and predictions of people displaced by environmental changes, Global Environmental Change, 21: 41-49, doi: 10.1016/j.gloenvcha.2011.09.005.

Gemenne, F. (2011b). How they became the human face of climate change: research and policy interactions in the birth of the "environmental migration" concept, u: E. Piguet, A. Pecoud, i P. de Guchteneire (ur.). Migration and Climate Change. Paris Cambridge: UNESCO Publishing - Cambridge University Press, 225-259.

Gemenne, F., Brücker, P. i Ionesco, D. (ur.) (2012). The State of Environmental Migration 2011. Paris - Geneva: Institute for Sustainable Development and International Relations (IDDRI) - International Organization for Migration (IOM).

Guha-Sapir, D., Hoyois, P. i Below, R. (2014). Annual Disaster Statistical Review 2013: The Numbers and Trends. Brussels: Centre for Research on the Epidemiology of Disasters (CRED).

Heršak, E. (2005). Drevne seobe: prapovijest i stari vijek. Zagreb: Školska knjiga.

Climate Change 2014: Synthesis Report (2014). Intergovernmental Panel on Climate Change (IPCC), http://www.ipcc.ch/pdf/assessment-report/ar5/syr/SYR_AR5_ LONGERREPORT_Corr2.pdf (08. 12. 2014.).

Jäger, J., Frühmann, J., Grünberger, S. i Vag, A. (ur.) (2009). EACH-FOR: Environmental Change and Forced Migration Scenarios (D.3.4. Synthesis Report). Budapest: ATLAS Innoglobe Ltd, http://seri.at/wp-content/uploads/2010/06/EACH-FOR_Synthesis_ Report_090515.pdf (08. 03. 2014.).

Kibreab, G. (1997). Environmental causes and impact of refugee movements: a critique of the current debate, Disasters, 21 (1): 20-38, doi: 10.1111/1467-7717.00042.

Kolmannskog, V. O. (2008). Future floods of refugees: a comment on climate change, conflict and forced migration. Oslo: Norwegian Refugee Council.

Manning, P. (2008). Migration in World History. New York: Routledge.

Mesić, M. (1992). Ekološke migracije, Socijalna ekologija, 1 (2): 167-177.

Mesić, M. (2002). Međunarodne migracije: tokovi i teorije. Zagreb: Societas - FF Press.

Morton, A., Boncour, P. i Laczko, F. (2008). Human security policy challenges, Forced Migration Review, 31: 5-7.

Münz, R. i Reiterer, A. F. (2007). Wie schnell wächst die Zahl der Menschen? Weltbevölkerung und weltweite Migration. Frankfurt a. M.: Fischer Verlag.

Myers, N. i Kent, J. (1995). Environmental Exodus: an Emergent Crisis in the Global Arena. Washington, DC: Climate Institute.

Myers, N. (2002). Environmental refugees: a growing phenomenon of the 21st century, Philosophical Transactions of the Royal Society B: Biological Sciences, 357 (1420): 609-613, doi: 10.1098/rstb.2001.0953.

Nordås R. i Gleditsch, N. P. (2007). Climate change and conflict, Political Geography, 26 (6): 627-638, doi: 10.1016/j.polgeo.2007.06.003.

Perrow, C. (2011). Normal Accidents: Living with High Risk Technologies. 3rd ed. Princeton: Princeton University Press.

Petersen, L. C. i Haug, G. H. (2005). Climate and Collapse of Maya Civilization, American Scientist, 93 (4): 322-329, doi: 10.1511/2005.54.968.

Petersen, W. (1970). A General Typology of Migration, u: C. Jansen (ur.). Readings in the Sociology of Migration. Oxford: Pergamon Press, 49-68, doi: 10.1016/b978-0-08006915-9.50008-5. 
Piguet, E. (2013). From "Primitive Migration" to "Climate Refugees": The Curious Fate of the Natural Environment in Migration Studies, Annals of the Association of American Geographers, 103 (1): 148-162, doi: 10.1080/00045608.2012.696233.

Rofi, A., Doocy, S. i Robinson, C. (2006). Tsunami mortality and displacement in Aceh province, Indonesia, Disasters, 30 (3): 340-350, doi: 10.1111/j.0361-3666.2005.00324.x.

Stern, N. (2007). The Economics of Climate Change: The Stern Review. Cambridge: Cambridge University Press, doi: 10.1017/cbo9780511817434.

Toynbe, A. J. (1987). Study of history, I-II. Oxford: Oxford University Press.

UNHCR (2014). Global trends 2013. Geneva: the UN Refugee Agency.

Wood, W. B. (2001). Ecomigration: Linkages between Environmental Change and Migration, u: A. Zolberg i P. Benda (ur.). Global Migrants, Global Refugees, Problems and Solutions. Oxford - New York: Berghahn Books.

Xu, X., Tan, Y. i Yang, G. (2013). Environmental impact assessments of the Three Gorges Project in China: issues and interventions, Earth-Science Reviews, 124: 115-125, doi: 10.1016/j.earscirev.2013.05.007.

Yonetani, M. (2014). Global Estimates 2014: People displaced by disasters. Geneva: Internal Displacement Monitoring Centre, Norwegian Refugee Council.

Zetter, R. (ur.) (2012). World Disasters Report 2012: Focus on Forced Migration and Displacement. Geneva: International Federation of Red Cross and Red Crescent Societies. 


\title{
Environmental Change and Human Migration
}

\author{
Milan Mesić, Drago Župarić-lljić
}

\begin{abstract}
SUMMARY
The 30-year anniversary of the journal Migration and Ethnic Themes (MET) is an occasion to announce a new key issue in the modern world's future, which, in the authors' opinion, is becoming the central theme within multidisciplinary and interdisciplinary field of migration studies. This concerns the displacement of people in the local and national context as well as migration across national borders, at the regional and global level, which are directly or indirectly caused by environmental change. The recent genetic studies on the origins and development of the human race further confirm that the human ecological migrations are the first and the oldest type of migrations at all. In addition, as archaeological and other findings suggest, just this type of migration sometimes played a key role in the emergence, decay and changing of ancient civilizations. It seems that the early researchers of migration studies had a lot in mind considering changes in natural environment as an important determinant of human spatial movements. The interest for this topic in the social sciences had trailed off until the re-emergence in the second half of the 1980s. The authors accept the classification on the causal categories of "environmental migration" as: a) "natural" disasters; b) "urban-industrial" disasters, and c) exploitation and degradation of resources. Further, they deal with the definition of basic concepts, first of all with disputes about the definition of "environmental refugees" as opposed to "environmental migrants". Finally, the authors systematize two major competing approaches to migration and migrants caused by environmental change. The first one is "the alarmist" and the second one "the sceptic" approach. Luckily, the Sceptics are able (for now) to prove that deterrent worse-case scenarios on increasingly powerful and unstoppable "waves" of environmental migrants (refugees) have not been achieved. This serves them as part of the argument that environmental drivers of human migration do not operate in isolation but in complex sets of economic, social and political (un)development of particular political communities and entire regions. However, neither they nor anyone else (unfortunately) can convincingly deny that a single cataclysmic natural disaster (such as the meteor strike on the Earth surface) may cause destruction of (part of) humanity, and conversion of large parts of our planet into a desolate area. If our (unnatural) civilization is doomed, environmental factors, by all odds, will be among its gravediggers.
\end{abstract}

KEY WORDS: environmental migration, environmental migrants, environmental refugees, environmental change, climate change 